\title{
組織における個人の転職行動に関する諸モデル
}

\author{
慶應義熟大学 \\ 武田圭太
}

\section{I ・はじめに一問題の所在一}

組織における人間行動 (organizational behavior) を 探究していくうえで, 個人の転職行動 (employee turnover behavior) は重要なトピックである。最近わが国 でも，転職に対する社会的な関心か高まる傾向にある。 「終身雇用が看板の『K K ニッポン』では，転職は㫒給， 昇進の面で不利だとされてきたか，それょりも自分の能 力をフルに発揮できるとてろ, 眗きがいのある職場を重 視する空気が，年々強まりつつある」（朝日新䦚，1984 年12月24日付)。『昭和60年版 労働白書』によれば，転 職希望率は昭和57，58年にかなりの高まりをみせており， 特に求職活動をしている転職希望者か5 58 年に增加してい る(学働省, 1985, p. 26)。

こうした情势は，いくつかの実態調査によっても襄付 けられている。日本リクルートセンター（1984）は，現 在サラリーマンとして勤務している者のうち， 3 人に 1 人は転職の意向をもっており，40.9\%が過去に転職した 経鍳をしつ，と報告している。また就職情報センター (1981)によれば，一般に転贈経跧者が少ないとされて いる大卒ホワイトカラーでも，2人に1人は転職するて とを考えており，入社後 5 年目がそのピークである。

てのような実態を, 組織心理学 (organizational psychology) での転職研究 (research on employee turnover）を進めていく立場から捉え直すと，その基本課避 のひとつは, 「特定の組織において, 成員 Aが組織に残 留し続けるのに対して，成員Bが組織を嵟れるのはなぜ か?」という問題の解明および理解にあるといえよう。 すなわち，ある一定の選抜基準を满たした結果新たに採 用された新成員は，理論的には皆一樣にその組織のなか で成長していく，と考えられるにもかかわらず，一部の 成員だけがそうでるいのはなぜか，という疑問である。

ての問題は，さらに2つの側面に分けて考えることが できる。ひとつは，「転職を促す個人要因および組織要 因は何か?」であり，いまひとつは，「転職あるいは残 留の意思決定に関連した心理学的過程はどのように記述
・説明されるのか?」である。前者は, 転職行動を基準 咨数とした場合の, 予測変数としての個人要因および組 織要因の特定化に焦点があてられる。また後者は, 転職 あるいは残留という外面的行動に至るまでの主として認 知的な過程が問われる。

Steers \& Mowday (1981) によれば, 過去25年間に, 転職に関する少なくとも13の文献研究が行われているか (Brayfield \& Crockett, 1955; Forrest, Cummings, \& Johnson, 1977; Herzberg et al., 1957; Lefkowitz, 1971; March \& Simon, 1958; Mobley et al., 1979; Muchinsky \& Tuttle, 1979; Pettman, 1973; Porter \& Steers, 1973; Price, 1977; Schuh, 1967; Stoikov \& Raimon, 1968; Vroom, 1964), その系譜をたどると，研 究の全体的な動向から当該の問題に関して次のような指 摘ができる。

転職の要因分析は，職務満足をはじめ多くの個人要因 および組織要因について論議されてきたが，組織要因の 方が個人要因よりもより大きな説明力をもつ，という見 解が示された (Spencer \& Steers, 1980; Wanous, Stumpf, \& Bedrosian, 1979)。しかしながら, 研究が 進むとともに，単一の変数では現象を充分に説明できな いという認識が深まり，しだいに二変量研究 (bivariate studies) に代って多変量研究 (multivariate studies) が盛んに行われるようになった。その結果, 転職に関す る諸要因の測定と評価は進展し, 必然的に二変量研究以 上の説明力をもつてとができるようになった。しかし， てのような多変量研究でさえも, 理論的に相互が関連づ けられた一群の変数を扱った例はそれほど多くはない (Clegg, 1983)。

そこで，転職行動のより系統立った理解を目指して， 概念モデルの必要性が主張された（Mobley et al., 1979; Wanous, 1980)。その場合, 単に転職の諸要因が 考察されるだけでなく，転職過程そのものが重視される。

したがって本稿では，眃職行動に䦎するいくつかの概 念モデルを要約し，また関連する諸研究を概観したうえ で，段後に，残された研究上の課題について言及して今 
後の問題提起としたい。

\section{II. 組織における転職過程の \\ 概念モテル}

転職の心理学的過程に関する概念モデルを構成するて とは，既知の経験的研究結果をより統合的に理解するう えで有効である (Mobley, $1982 \mathrm{a}$; Mobley et al., 1979; Steers \& Mowday, 1981)。March \& Simon （1958）は，職務満足と代替的職務機会を主要因とする概 念モデルを提示したが，ここで取り上げる他のモデルは， いずれもての考え方を前提とし，さらに新たな知見が加 味されて構成されたものである。そしててれらの要因は， わが国の組織における転職行動を考えるうえでも同様に 重要であることから, 既存の諸モデルを当該現象理解に 向けての探索道具として検討するてとは有意義だと考え られる。

\section{March \& Simon モデル}

March \& Simon (1958) の参加の意思決定モデルは, (1)組織から移動するてとについての知覚された desirability（Fig.1）と，(2)組織加ら移動するてとについての 知覚された容易さ (Fig. 2), という $2 つ$ 構成要素から なる。

組織から移動するてとについての知覚された desirability は, (1)職務満足と, (2)組織队での異動についての

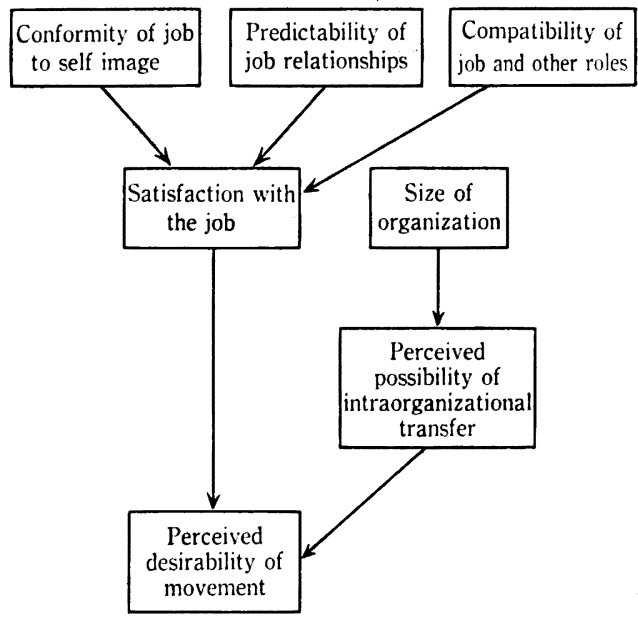

Fig. 1 Major factors affecting perceived desirability of movement

Source: J. G. March \& H. A. Simon (1958)

Organizations. New York: John Wiley \& Sons, p. 99.



Fig. 2 Major factors affecting perceived ease of movement

Source: J. G. March \& H. A. Simon (1958) Organizations. New York: John Wiley \& Sons, p. 106.

知覚された可能性の関数と考えられる。さらにての場合， 職務満足は, (1)職務と自己イメージとの適合性, (2)職務 上の諸関係についての予測可能性，(3)職務と他の役割と の両立性の関数であり，また組織内での異動についての 知覚された可能性は, 組織規模の関数とみなされる。

また組織から移動するてとについての知覚された容易 さは，知覚された組織外での代替的選択肢の数の関数と 考えられる。そしてての場合, 知覚された組織外での代 替的選択肢の数は，(1)経済活動の水準，(2転職先として 認知された組織の数，(3)参加者の個人的諸特徽の関数と みなされる。さらに，転職先として認知された組織の数 は，(1)個人の探索の性向と，(2)個人の転職先の認知度の 関数として，また個人の転職先の認知度は，(1)転職先と して認知された組織の数と，(2)参加者の個人的諸特性の 関数として考えられる。

ての March \& Simon モデルに関して, Pettman (1973) は, 当該モデルのパースペクティウかから文献研究 を行い，次のような結論を下した。

移動についての知覚された desirability に関して, (1)転職の必要条件ではなく十分条件としての職務不満足, (2)職務上の手段的諸関係についての予測可能性と職務淽 足との間に仮定された関係性，(3就業時間パターンに対 する他の役割との間の適合性と，職務満足および転職と の関係性，(4)職務と自己イメージとの適合性は，職務満 足および転職と関連しているという仮説，(5)職場集団の 
規模, 報酬, 学歴, 組織内での異動にらいての知覚され た可能性を合む諸仮説，の各々が，一貫して経験的に支 持されている。

また移動についての知覚された容易さに関しては，(1) 失業水隻と転職率との間に仮定された関係性が実証され たこと，(2)年龄や勤続期間，專門化に関する諸仮説が支 持されたとと, (3)参加者の性別や社会的地位に関する諸 仮説は, 不確かな支持しか得られなかったとと, の各々 が明らかにされた。

\section{Price モデル}

Price (1975, 1977) は, 従属変数である転職に対し て, (1)貨金水準，(2)統合性，すなわち第一次集団ないし 準第一次集団への参加の程度，(3)役割遂行に直接関係す る手段的コミュニケーション, (4)事務的に伝達される公 式のコミュニケーション, (5)集権性 (centralization), すなわち権力（power）の集中度，の5つを独立変数と する概念図式を提示した（Fig.3）。との場合，集権性の みが転職とポジティヴに関係し，他の 4 つの変数はいず れもネガティヴな関係をもつと考えられる。

さらに，との 5 つの独立変数と転職との間には， March \& Simon が注目した(1满足度，すなわち組織成 員が，参加する組織の成員性に対してポジティヴな態度 指向をもつ程度と，(2機会，すなわち環境における代替

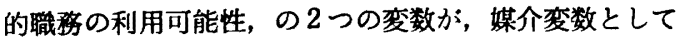
特定化された。ただし满足度は, 職務を遂行することで 得られる利益と被る損失とのバランスに起因する。

そして Price モデルの基本仮説は，媒介変数間には 相互作用があり，機会が相対的に大きい場合にのみ，不 满足感の結果としての転職が生ずるということである。

しがし Bluedorn (1982) は, Price モデルに関する いくつかの検証研究を検討した結果，すべての研究が職

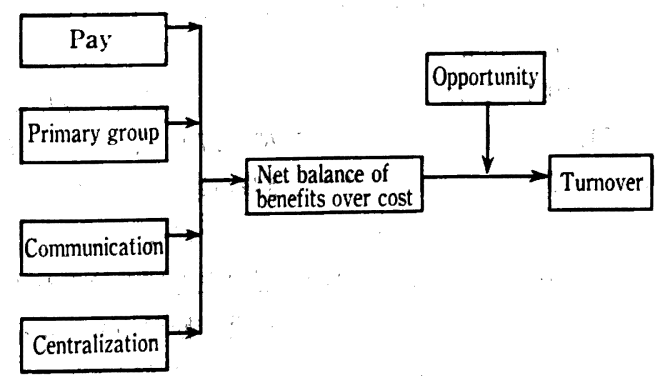

Fig. 3 Theory of turnover Source: J. L. Price (1975) A theory of turnover. In. B. O. Pettman (Ed.), Labour turnover and retention. Epping, Essex: Gower Press, p. 73.
務満足と機会との相互作用を否定している，と報告した。 ただし，機会が因果関係上は職務满足に先行し，職務満 足を媒介して間接的に転職に影幚する，という考え方は 支持されている。したがって，機会を職務満足要因のひ とつとみなすことができる (Bluedorn, 1982) が, この 点についてはさらに考察が必要であろう。

\section{Mobley モデル}

Mobley (1977) は, 満足度と転職との間のネガティヴ な関係性をより詳紐に考察し，職務に対する低い满足度 が実際の転職行動へと結びつくまでの喼知的な諸過程を モデル化した（Fig.4）。

Mobley モデルは, (1)現在の職務についての評価から， (2)職務に対する满足感あるいは不满足感が生じ，不满足 感が大きい場合，それが(3)離職を考えるととを促し，(4) 代替的選択肢について期待される効用性と離職によって もたらされる犠牲とを評価したうえで，(5)代替的選択肢 を探索する意向を固め, (6)実際に探索し，その結果(7)認 知された代替的選択肢を評価し，8現在の職務との比較 をふまえて，(9辞めるか留まるかの意向を固め，最終的 には110離職か残留のいずれかの外面的行動が表出される， という一連の転職意思決定過程である。モデル全体は, いくつかの認知的段陼の時間的連鎖によって構成されて いるが，各段階から先行する段階へのフィードパック・

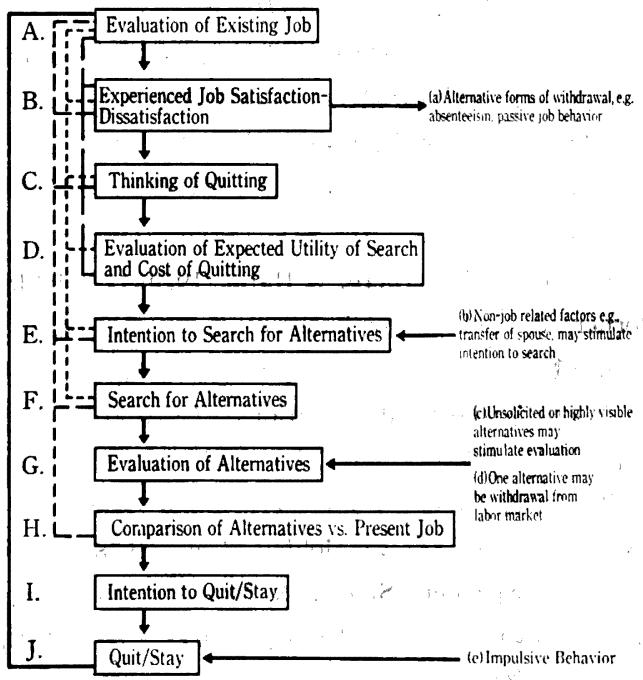

Fig. 4 The employee turnover decision process

Source: W.H. Mobley (1977) Intermediate linkages in the relationship between job satis. faction and employee turnover. Journal of Applied Psychology, 62, p. 238. 
ループも考虑されている。

このモデルの特徽は, 転職のより直接的な予測変数と して, 職務満足度ではなく転職の意向 (intention) に着 目する点にある。すなわち Mobley は, March \& Simon や Price の職務満足と転職行動との関係について の議論を, 転職意向という新たな概念を用いてより詳細 に展開したということができる。意向は，態度と行動の 結びつきを理解するうえでFishbein (1967) によって強 調された概念である。そして，転職の意向が最も有効な 予測変数であり, 転職の意向に先行する他の諸変数は, 職務満足度も含めて, 転職の意向以上の予測力をもたな いという仮説は，経験的に支持されている。

Gupta \& Beehr (1979) は, デモグラフィック要因に 着目し，転職の意向および自発的転職との間の関係を分 析した結果，転職の意向と自発的な転職との間には有意 な関係の認められたととを報告している。また Martin (1979) の研究は, 組織に留まるか辞めるかの意向に関す る予測変数を明らかにするために行われた。それによる と, 組織の構造変数のなかで上方移動が, また媒介変数 としての瞕務満足が, さらにデモグラフィック変数のう ちで教育と年齢が，各々重要である。さらに Martin \& Hunt (1980) は, 転職の意向に関して, 社会的勢力 (social power) 変数, リーダーシップ行動変数, 集団の 凝集性, 職務满足, バィオグラフィカル変数を用いてパ ス解析したところ，(1)社会的勢力はリーダーシップ行動 へ影蠁すること, (2)集団の凝集性は職務满足に影響する こと, (3)職務滥足は雄職の意向に影響するとと，また(4) リーダーシップ行動は離職の意向に影響しないてと，(5) 集団の凝集性は離職の意向に影豐しないこと、が明らか になった。

一方 Miller, Katerberg, \& Hulin (1979) は, Mobley, Horner, \& Hollingsworth (1978) モデルの検証研究を 行い, 職務嗬足とキャリア移動（年齢, 在職期間, 職務 機会）は, withdrawal cognitions（離職の意向, 職務 探索の意向, 離職を考えるとと）を媒介したときに限っ て転職に影幚するてとが実証され，モデルの経験的な多 当性が支持された。この Mobley et al. (1978) モデル について, Spencer, Steers, \& Mowday (1983) は, 当該モデルの榆証および Mobley (1977) によって提示 された(1)代替的職務の探索の仵囲と(2)代替的職務の探索

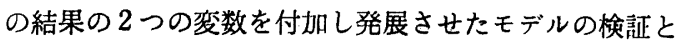
を行った。その結果, Mobley et al. (1978) モデルは 支持されたが，その発展モデルについては，新たに付け

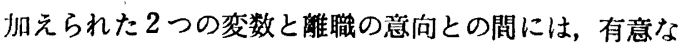
関係は認められなかった。

\section{Wanous モデル}

Wanous（1980）は，個人と組織の調和（matching individual and organization) というパースペクティヴ から転職について考察した。Wanous の個人と組織の調 和モデルは, 組織の観点と個人の観点の 2 つの側面をも つ。

組織の観点では, 個人の現在および将来の能力と組織 の職務遂行に必要な条件との間の調和過程が問題となる。 そしてての調和の結果は, 直接的には職務遂行に, また 職務遂行を通じて間接的には非自発的転職に影艟する。

個人の観点では, 個人の欲求とそれを充足させうる組 織風土との間の調和過程に焦点があてられる。この調和 の結果は, 直接的には職務満足と組織へのコミットメン トにまた，それらを通じて間接的には自発的転職に影 留する。

てのように Wanous モデルでは, 自発的転職と非自 発的転職が明確に区別されているのが特徽である。両者 を区別した研究として, Stumpf \& Dawley (1981) は, (1)無断欠勤 (absenteeism) および職務遂行と自発的, 非自発的転職との関係性を, いくつかの個人特性変数と 関連づけながら分析し，さらに(2)乙れらの変数間の関係 性の変化を, 各々異なる時代背景をもつ 2 つの研究対象 群に関して考察した。その結果, いくつかの個人特性変 数および無断欠勤，職務遂行は, 自発的転職と非自発的 転職のいずれとも有意に関係するが，しかし無断欠勤や 嬂務遂行に比べると個人特性要因の説明力は小さいとと が示された。また，ての絬果が継時的にどの程度の変化 を示すかについて, Stumpf \& Dawley は, 同じ銀行に 1970年から1976年の間に雇用された人たち $(n=354)$ と 1977年から1978年の閒に雇用された人たち $(n=242)$ の 2つの対象群を比較することで言及している。それによ ると, 若干の個人特性変数および唚断欠勤, 職務遂行と 転職との関係は，1970１976年の集団では，自発的転職 に関して $R^{2}=.44$, 非自発的転職に関して $R^{2}=.55$ であ るのに, 1977〜1978年の集団では，自発的転職に関して $R^{2}=.71$, 非自発的枟職に関して $R^{2}=.79$ と, 後者の方 が強まっている。とのてとから予測変数と基準変数との 関係性が継時的に変化するてとが明らかになった。

さらに Wanous は，転職の意思決定過程を示すため に, 調和モデルをより㧓大させた自発的転職のモデルを 提示した (Fig. 5)。乙のモデルでは, 嬂務满足と組織へ のコミットメントの決定因として, 個人の欲求と組織風 土の調和の他に，現在の職務と代替的職務との比較が考 虑されている。そして職務満足および組織へのコミット メントの程度は, 別の職務を得るという行為を通じて自 


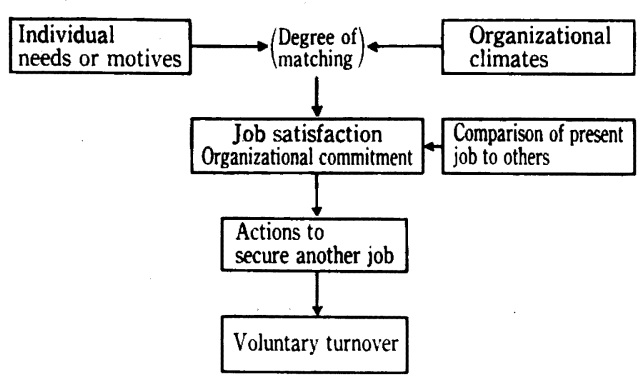

Fig. 5 Expanded model of voluntary turnover

Source: J. P. Wanous (1980) Organizational entry. Reading, Massachusetts: Addison-Wesley, p. 112.

\section{発的転職と関連する。}

Wanous が注目した職務へのコミットメントの程度は, ひとつの重要な転賱の予測変数である (Porter, Crampon, \& Smith, 1976; Porter et al., 1974)。しかし Wanous モデルでは, 職務満足と組織へのコミットメン トとの関係性が必ずしも明確ではないと考えられる。

\section{Farrell \& Rusbult モテル}

Farrell \& Rusbult (1981) は, 職務満足と組織への コミットメントを明らかに区別し，転職の予測変数とし て, 職務満足よりも職務へのコミットメントを重視する 観点から，職務満足およびュミットメントと転職との相 互関連性に関する Investment モデルを提示した。

それによると，まず職務満足，すなわち個人が自分の 職務をポジティウに評価する程度は，職務がもたらす報 酬と職務に従事するととで被る損失の差と考えられる。

Satisfaction $=$ Rewards - Costs.

次に職務へのコミットメント，すなわち職務満足度と は無関係に，個人が自分の職務に固執し愛着を感じる程 度は，職務満足とインヴェストメント，すなわち職務に 従事し続けるてとによって得られる諸資源（例えば，勤 続期間，他では習得できないような技能など）および代 替的選択肢に規定されるとする。したかっって，報酬が減 少し; 損失が増大し，インヴェストメントが減少し，さ らに代替的選択肢の質が増加するとコミットメントは低 下し，それが転職を引き起てすと考えられる。

Commitment $=($ Rewards - Costs $)+$ Invest -

ment size-Alternative quality.

Rusbult \& Farrell (1983) は, このモデルの予测力を 検証するために，1年間にわたる繸断的研究を行った。 その結果, 報酬が增加し, 提失が堿少するほど職務满足
度は高まり，また職務へのより高いコミットメントは， 高い報酬と低い損失，大きなインヴェストメント資源， そしい代替的選択肢によって促進されるてとが実証され， モデルは経匼的に支持された。

さらに報酬と損失，インヴェストメント，代替的選択 肢の 4 つの変数に関して興味深いととは，ある特定の時 点においては転職者と残留者の間には実質的な有意差が みられないととである。すなわち，転職者と残留者を区 分するのは変化の過程 (process of change) そのもので あり,とりわけ転職の意思決定に影響する最も重要な変 化の過程は, コミットメント低下の過程である。

これらの他には, Mobley et al. (1979) や Steers \& Mowday（1981）などは，個人レヴェルや組織レヴェル にとどまらず，マクロな社会レヴェルにおける諸要因を も考虑したより包括的な統合モデルを提示している。

以上の諸モデルについて，そのいくつかを相互に比較 考察した研究も行われている。Hom, Katerberg, \& Hulin（1979）は，転職の予測に関する3つのアプロー チ, すなわち Fishbein (1967) の行動の意向（behavioral intention) モデル, 職務満足, Porter (Porter, Crampon, \& Smith, 1976; Porter et al., 1974) の組 織へのコミットメント・モデルを比較した結果, 職務满 足に比べると, Fishbein モデルや組織へのコミットメン ト・モデルの方がより正確に転職を予測することが明ら かになった。また Bluedorn (1982) は, Price (1977) モデルと Mobley (1977) モデル, それに組織へのコミ ットメント・モデルを結合させ,より統合的な転職過程 モデルを提示し, 同時にその検証を行った。その結果, 当該モデルは経験的に支持された。

しかしながら既存モデルには，まだ多くの問題点が残 っており, それに関して Mowday, Porter, \& Steers （1982）は次の 8 つの点を指摘した。

(1) 個人が参加の意思決定を行う際に, 現在の職務あ るは将来の職務に関する情報が果たす役割を，てれまで のモデルの多くは無視している。

(2) 職務に関して個人が抱く期待や洒値観が，組織で の実際の経験によって実現する程度は重要な要因である にもかかわらず，てれまでのモデルの多くは無視してい る。

(3) 離職の願望や意向に影響する要因としての職務遂 行水準もまた見落とされている。

(4) 職務態度に関して, 職務満足度以外の態度変数 (例えば, 組織へのコミットメント，職務インヴォルヴ メントなど）が無視されている。

(5) 転職に対する仕事以外の影爵内（例えば，家族に 
関わる問題, 趣味など）も一貫して無視されてきた。

(6) これまでのモデルの大半は，個人がひとたび職務 に不満足感を抱くと，その感情がそのまま実際の転職行 動へと結びっくという仮定に依拠しているが，てうした 仮定は，個人は現在の職場情況を変え得るかもしれない という事実を無視している。

(7) 利用可能な代替的職務機会の果たす役割に関して, そのような利用可能性の知覚に影掣する諸要因と，個人 がうした代替的職務機会を知覚できなかった場合の結


を武みるべきである。

(8)てれまでのモデルは, 離職の願望または転職行為 を，助長したり改めたりし得るようなフィードバック・ ループ (例えば, 職場環境を変えようと武みること,な ど）を無視している。

\section{III. むすびに一今後の課题一}

Mobley (1982b) は, 転職研究の今後の課題として, (1)転職を“過程”として経験的にとらえる工夫をするて と，(2)転職結果に注目するてと，(3)職務遂行と転職との 関係に着目すること，(4)転職と他の withdrawal behaviors との関係を明らかにするてと，を指摘している。

転職現象を過程とみなすととによって，その継時的な 変化やフィードバック，相互作用などが研究の対象とな ってくるが，綐断的研究デザインはそれらを経覧的にと らまえるうえで有効である。Youngblood，Mobley，\& Meglino（1983）は，アメリカ海兵隊員を対象に，転職 に関する Mobley et al. (1979) の概念モデルの主要な 統合的構成要素を予測変数とする縦断的研究を行った。 それによると，転職者と残留者とでは明らかに継時的な 有意差が認められ，特に転職者の場合，留まろうとする 行動の意向 (behavioral intentions to stay) か実際の 転職の直前で急激に低下する特徵がみられた。ての他に もいくつかの縋断的研究が行われているが（例えば,

Farrell \& Rusbult, 1981; Graen \& Ginsburgh, 1977; Porter, Crampon, \& Smith, 1976), 多くはない。

また転職を過程として考えるととは，自ずとその諸絬 果が先行要件と関連しつつ問題となってくる。Dalton, Todor, \& Krackhardt (1982) および Mowday, Porter, \& Steers (1982) は，すへてて転職が必ずしも望 ましくないわけではないとして，転職がもたらすポシ ティブな諸結果を強調した。また Steers \& Mowday （1981）は，転職の組織に対する影響を，特に同僚の転 職が牫留者に及ぼす影響について考察した。

職務遂行と枟職との関係については，次のような閔題
点があげられる (Mobley，1982b)。(1)高い職務遂行者 は，外部の代替的選択肢をより多く知覚し所有している のか?，(2)知覚された代替的選択肢がない場合，離職の 願望あるいは意向を抱いている高い職務遂行者は, 職務 遂行を加诚するのか?，(3)高い職務遂行者にとって，付 随する勤務成縝非関連報酬システム（nonperformancecontingent reward systems) は転職を助長するのか?， (4)職務遂行水準は個人によって異なるが，離職は残留者 に対して，特にその職務遂行にどのような結果をもたら すのか?，(5) 職務遂行水準が各々異なる諸個人につい て，転職の効用はどのように指標化できるのか？Keller （1984）は，転職を予測するうえでの職務遂行および無断 欠勤 (absenteeism) の果たす役割を, Mobley et al. (1979）モデルによって示された変数と関連させながら 考察した。その絬果，低い職務遂行および高い哭断欠勤 率は転職に対して有意な予測力をもつてとが明らかにな つた。

さらに withdrawal behaviors と転職との関係につい ては, Mowday, Porter, \& Steers (1982) が, 組織へ のコミットメント，無断欠勤，そして転職というそれぞ れ異なった現象を，個人と組織との “結びつき” (linkage）という単一の観点から考察している。

また転職は，転嬂者の生活情況の年秢による違いに よってその意味合いが異なるため, 個人の発達現象に 関心を寄世る他の研究領域との関連を導くといえる。な かでもキャリア発逹研究におけるキャリア変化（career change）現象とは，多くの重複する部分をもつ（Krau, 1981; Mihal, Sorce, \& Comte, 1984; Rhodes \& Doering, 1983; 武田, 1984)。したがって，ての2つの 領域の統合化は，転職現象の体系的な理解人向けての残 されたもうひとつの謎題といえるであろう。

\section{引用文 献}

朝日新闻 1984 年12月24日付.

Bluedorn, A.C. 1982 A unified model of turnover from organizations. Human Relations, 35, $135-153$.

Brayfield, A. H., \& Crockett, W.H. 1955 Employee attitudes and employee performance. Psychological Bulletin, 52, 396-424.

Clegg, C. W. 1983 Psychology of employee lateness, absence, and turnover: A methodological critique and an empirical study. Journal of Applied Rsychology, 68, 88-101.

Dalton, D. R., Todor, W.D., \& Krackhardt, D. M. 1982 Turnover overstated: The functional taxonomy. Academy of Management Revicw, 7, 117-123. 
Farrell, D., \& Rusbult, C. E. 1981 Exchange variables as predictors of job satisfaction, job commitment, and turnover: The impact of rewards, costs, alternatives, and investments. Organizational Behavior and Human Performance, 28, 78-95.

Fishbein, M. 1967 Attitude and the prediction of behavior. In M. Fishbein (Ed.'), Readings in attitude theory and measurement. New York: John Wiley \& Sons.

Forrest, C.R., Cummings, L. L., \& Johnson, A. C. 1977 Organizational participation: A critique and model. Academy of Management Review, 2, 586-601.

Graen, G. , \& Ginsburgh, S. 1977 Job resignation as a function of role orientation and leader acceptance: A longitudinal investigation of organizational assimilation. Organizational Behavior and Human Performance, 19, 1-17.

Gupta, N., \& Beehr, T. A. 1979 Job stress and employee behaviors. Organizational Behavior and Human Performance, 23, 373-387.

Herzberg, F., Mausner, B., Peterson, R. O., \& Capwell, R. 1957 Job attitudes: Reviev of research and opinions. Pittsburgh: Pittsburgh Psychological Services.

Hom, P. W. , Katerberg, R. Jr. , \& Hulin, C. L. 1979 Comparative examination of three approaches to the prediction of turnover. Journal of Applied Psychology, 64, 280-290.

Keller, R. T. 1984 The role of performance and absenteeism in the prediction of turnover. Academy of Management Journal, 27, 176183.

Krau, E. 1981 Turnover analysis and prediction from a career developmental point of view. Personnel Psychology, 34, 771-790.

Lefkowitz, J. 1971 Personnel turnover. Progress in Clinical Psychology, 69-90.

March, J. G., \& Simon, H. A. 1958 Organiza . tions. New York: John Wiley \& Sons. (土 屋守管 訳 1977 オーガニゼーションブ ダイ ヤモンド社)

Martin, T.N. Jr. 1979 A contextual model of employee turnover intentions. Academy of Management Journal, 22, 313-324.

Martin, T. N., \& Hunt, J.G. 1980 Social influence and intent to leave: A path-analytic process model. Personnel Psychology, 33, 505-528.

Mihal, W. L., Sorce, P.A., \& Comte, T. E. 1984 A process model of individual career decision making. Academy of Management Review, 9, 95-103.

Miller, H. E., Katerberg, R., \& Hulin, C. L.
1979 Evaluation of the Mobley, Horner, and Hollingsworth model of employee turnover. Journal of Applied Psychology, 64, 509-517.

Mobley, W.H. 1977 Intermediate linkages in the relationship between job satisfaction and employee turnover. Journal of Applied Psychology, 62, 237-240.

Mobley, W.H. 1982a Employee turnover: Causes, consequences, and control. Reading, Massachusetts: Addison-Wesley.

Mobley, W.H. 1982b Some unanswered questions in turnover and withdrawal research. Academy of Management Review, 7, 111116.

Mobley, W. H. , Horner, S. O., \& Hollingsworth, A.T. 1978 An evaluation of precursors of hospital employee turnover. Journal of $A p$. plied Psychology, 63, 408-414.

Mobley, W. H., Griffeth, R. W., Hand, H. H., \& Meglino, B. M. 1979 Review and conceptual analysis of the employee turnover process. Psychological Bulletin, 86, 493-522.

Mowday, R. T., Porter, L. W., \& Steers, R. M. 1982 Employec-organization linkages: The psychology of commitment, absenteeism, and turnover. New York: Academic Press.

Muchinsky, P. M., \& Tuttle, M.L. 1979 Employee turnover: An empirical and methodological assessment. Journal of Vocational Behavior, 14, 43-77.

日本リクルートセンター 1984 転職に関する実隼およ び意識調査 リクルート調查月報, 9，131-169.

Pettman, B. O. 1973 Some factors influencing labour turnover: A review of the literature. Industrial Relations Journal, 4, 43-61.

Porter, L. W., \& Steers, R. M. 1973 Organizational, work, and personal factors in employee turnover and absenteeism. Psychological Bulletin, 80, 151-176.

Porter, L. W., Crampon, W. J., \& Smith, F. J. 1976 Organizational commitment and managerial turnover: A longitudinal study. Organizational Behavior and Human Performance, 15, 87-98.

Porter, L. W., Steers, R. M. , Mowday, R. T. , \& Boulian, P. V. 1974 Organizational commitment, job satisfaction, and turnover among psychiatric technicians. Journal of Applicd Psychology, 59, 603-609.

Price, J. L. 1975 A theory of turnover. In B. O. Pettman (Ed.), Labour turnover and retention. Epping, Essex: Gower Press.

Price, J. L. 1977 The study of turnover. Ames, Iowa: Iowa State University Press.

Rhodes, S. R., \& Doering, M. 1983 An integ- 
rated model of career change. Academy of Management Review, 8, 631-639.

学做省 1985 昭和60年版 労働白書

Rusbult, C. E., \& Farrell, D. 1983 A longitudinal test of the investment model: The impact on job satisfaction, job commitment, and turnover of variations in rewards, costs, alternatives, and investments. Journal of Applied Psychology, 68, 429-438.

Schuh, A. J. 1967 The predictability of employee tenure: A review of the literature. Personnel Psychology, 20, 133-152.

就職情報センター 1981 大卒ホワイトカラーの転職に 関する調査.

Spencer, D. G., \& Steers, R. M. 1980 The influence of personal factors and perceived work experiences on employee turnover and absenteeism. Academy of Management Journal, 23, 567-572.

Spencer, D. G., Steers, R. M., \& Mowday, R. T. 1983 An empirical test of the inclusion of job search linkages into Mobley's model of the turnover decision process. Journal of Occupational Psychology, 56, 137-144.

Steers, R. M., \& Mowday, R. T. 1981 Employee turnover and the post decision accommodation processes. In L. L. Cummings \& B. M.
Staw (Eds.), Research in organizational behavior (Vol. 3). Greenwich, Connecticut: JAI Press.

Stoikov, V., \& Raimon, R. L. 1968 Determinants of differences in the quit rate among industries. American Economic Review, 58, 1283-1298.

Stumpf, S. A., \& Dawley, P.K. 1981 Predicting voluntary and involuntary turnover using absenteeism and performance indices. Academy of Management Journal, 24, 148-163.

武田圭太 1984 中年期の転職一キャリア発達論的観点 加らの若干の考察一 慶應義塾大学大学院社会学 研究科紀要, 24, 35-44.

Vroom, V.H. 1964 Work and motivation. New York: John Wiley \& Sons.

Wanous, J. P. 1980 Organizational entry. Reading, Massachusetts: Addison-Wesley.

Wanous, J.P., Stumpf, S. A., \& Bedrosian, H. 1979 Job survival of new employees. Personnel Psychology, 32, 651-662.

Youngblood, S. A., Mobley, W. H., \& Meglino, B. M. 1983 A longitudinal analysis of the turnover process. Journal of Applied Psy. chology, 68, 507-516.

-1985 年 4 月 26 日 受稿, 1985 年 9 月 19 日 受理一 